\title{
FEEDING HABITS OF THE LEOPARD GROUPER, MYCTEROPERCA ROSACEA (ACTINOPTERYGII: PERCIFORMES: EPINEPHELIDAE), IN THE CENTRAL GULF OF CALIFORNIA, BCS, MEXICO
}

\author{
Xchel G. MORENO-SÁNCHEZ1, Pilar PEREZ-ROJO¹, Marina S. IRIGOYEN-ARREDONDO, \\ Emigdio MARIN- ENRÍQUEZ ${ }^{2}$, Leonardo A. ABITIA-CÁRDENAS ${ }^{1 *}$, \\ and Ofelia ESCOBAR-SANCHEZ ${ }^{2}$ \\ ${ }^{1}$ Instituto Politecnico Nacional, Centro Interdisciplinario de Ciencias Marinas (CICIMAR-IPN), \\ Departamento de Pesquerías y Biología Marina La Paz, BCS, Mexico \\ ${ }^{2}$ CONACYT-Universidad Autónoma de Sinaloa-Facultad de Ciencias del Mar (CONACYT UAS-FACIMAR) \\ Mazatlán, SIN, Mexico
}

Moreno-Sánchez X.G., Perez-Rojo P., Irigoyen-Arredondo M.S., Marin- Enríquez E., Abitia-Cárdenas L.A., Escobar-Sanchez O. 2019. Feeding habits of the leopard grouper, Mycteroperca rosacea (Actinopterygii: Perciformes: Epinephelidae), in the central Gulf of California, BCS, Mexico. Acta Ichthyol. Piscat. 49 (1): 9-22.

Background. The leopard grouper, Mycteroperca rosacea (Streets, 1877), is endemic to north-western Mexico and has high commercial value. Although facts of its basic biology are known, information on its trophic ecology, in particular, is scarce. The objective of the presently reported study was to characterize the feeding habits of $M$. rosacea through the analysis of stomach contents, and to determine possible variations linked to sex (male or female), size (small, medium, or large), or season (spring, summer, autumn, or winter), in order to understand the trophic role that this species plays in the ecosystem where it is found.

Materials and methods. Fish were captured monthly, from March 2014 to May 2015 by spearfishing in Santa Rosalía, BCS, Mexico. Percentages by the number, by weight, and frequency of appearance of each food category, the index of relative importance (\%IRI), and prey-specific index of relative importance (\%PSIRI) were used to determine the importance of each prey item in the leopard grouper diet. Diet breadth was calculated using Levin's index. Possible differences in the diet by sex, size, or season were identified through a multivariate PERMANOVA analysis.

Results. A total of 341 leopard grouper specimens were collected, 309 of which had stomachs containing food. A total of 28 prey species were identified. According to the \%IRI, the contribution to the diet of the coastal pelagic prey Nyctiphanes simplex and Sardinops sagax (Jenyns, 1842) was $87 \%$, whereas according to the \%PSIRI the contribution to the diet of those two prey species was $57 \%$, in addition to several demersal prey species. A PERMANOVA analysis indicated that there were significant differences in the diet of leopard grouper by sex, size, and season, but the interactions sex-size, sex-season, size-season, and sex-size-season, were not significant. Conclusions. Mycteroperca rosacea was identified as a carnivorous predator with narrow trophic width, with significant differences in diet according to the sex, size, season, and size-sex interactions, which could be the result of different energetic requirements, hunting abilities, and food availability. The \%PSIRI turned out to be the most adequate index to determine the feeding habits of fish, as it provides a better mean value to determine the most important prey.

Keywords: stomach contents, diet breadth, Gulf of California, euphausiids, sardines

\section{INTRODUCTION}

The perciform family Epinephelidae (previously subfamily Epinephelinae within the family Serranidae), commonly known as groupers, is an assemblage of reef fishes comprising more than 160 species in 16 genera
(Craig et al. 2001, Zhuang et al. 2013). The commercial interest in this group in tropical and subtropical regions (Heemstra and Randall 1993) has made it vulnerable, and a decrease in abundance and mean catch sizes has been observed. Behavioural adaptations such as spawning 
aggregations have placed groupers under considerable fishing pressure (Sadovy 1994, Craig et al. 2001). Based on the feeding habits and trophic interactions of the family Epinephelidae it has been determined that these fishes are one of the main predators of rocky and coral reef environments (Mullaney 1994, Brulé et al. 2005, Dierking et al. 2009, Condini et al. 2011, 2015). These fishes are characterized by having the ability to predate on benthic prey as well as on prey in the water column, which leads them to play a key role in the maintenance of the communities they inhabit (Goeden 1982, Parrish 1987, Randall 1998, Helfman et al. 2009, Taylor unpublished*).

The leopard grouper, Mycteroperca rosacea (Streets, 1877), is endemic to north-western Mexico. It has great commercial importance, with an estimated annual catch of 5000 t in the GulfofCalifornia (GC)(Anonymous 2013). It has been classified as 'least concern' in the red list of threatened species of the International Union for the Conservation of Nature (Erisman and Craig 2018). Despite this, studies on its basic biology are insufficient, even more so regarding its feeding habits in the wild, which are indispensable to obtain a better perception of the functional role this species plays in marine ecosystems. Feeding habits help to understand trophic relations among members of a community. They also help to determine trophic levels, feeding regimes, types of diet, and general energy flows in trophic webs, and thus the trophic role of studied species in their habitat (Hyslop 1980, Amezaga Herrán 1988, Krebs 1989).

Members of the genus Mycteroperca have feeding habits that characterize them as being mainly generalist carnivores (consuming predominantly fish and invertebrates) with changes in diet due to size, sex, season, and habitat type (Mullaney 1994, Brulé et al. 2005, Condini et al. 2011, 2015). Studies have been carried out on the feeding behaviour and trophic ecology of $M$. rosacea in the GC, such as that of Hobson (1968) who, based on the study of the predatory behaviour of $M$. rosacea in three areas of the southern $\mathrm{GC}$, reported that large individuals $(>25 \mathrm{~cm})$ inhabiting rocky substrates at less than $50 \mathrm{~m}$ depth fed after sunset, and that their main prey was the Pacific flatiron herring, Harengula thrissina (Jordan et Gilbert, 1882), whereas juveniles ( $<25 \mathrm{~cm}$ TL) fed all day long on highly available resources such as crustaceans and small fishes.

Parrish (1992) quantified the incidence of diurnal predation on schools of several hundred thousand adult Pacific flatiron herring, Harengula thrissina, in the GC (Puerto Escondido, BCS), and reported that nine species of fish predators carried out 653 attacks and 158 captures during $42.5 \mathrm{~h}$ of observation. Four predators, such as leopard grouper, M. rosacea; cornetfish, Fistularia commersonii Rüppell, 1838; green jack, Caranx caballus Günther, 1868; and black skipjack, Euthynnus lineatus Kishinouye, 1920; were responsible for $92 \%$ of attacks and $96 \%$ of successes.

Thomson et al. (2000) undertook a study of the rocky shore fishes of the GC and reported that the leopard grouper was essentially a shallow-water crepuscular predator that aggregated over rocky outcrops in the middle of the day, when it was relatively inactive. After sunset it began to feed voraciously on herring or anchovies, seeming to prefer to feed on schools of Pacific flatiron herring, Harengula thrissina.

In this context, the presently reported study was carried out in order to establish the feeding habits of the leopard grouper, M. rosacea. We assumed that this species would present the same feeding pattern as other members of the genus, i.e., a generalist carnivorous predator, with changes in its diet according to sex (male or female), size (small, medium, or large), or climatic season (spring, summer, autumn, or winter).

The index of relative importance (IRI) proposed by Pinkas et al. (1971) has been the combined method most frequently used to characterize and determine the importance of prey species in fish trophic spectrums. Brown et al. (2012) analysed and discussed the pertinence of the IRI; they highlighted that its calculation incorporates sources of error and variation, and proposed the preyspecific index of relative importance (\%PSIRI), in which they performed a mathematical correction to the IRI to avoid those errors in the determination of prey importance. However, this latter index has been little used, and therefore in the presently reported study we contrast and discuss results obtained using the two methodological approaches.

\section{MATERIALS AND METHODS}

The sampling of Mycteroperca rosacea was carried out monthly from March 2014 to May 2015 in the Central Gulf of California, in the region of Santa Rosalía, at approximately $27^{\circ} 20^{\prime} \mathrm{N}, 112^{\circ} 16^{\prime} \mathrm{W}$ (Fig. 1). Leopard grouper specimens were captured by free diving using a spear during the crepuscular period (05:00 to 08:00 h), which is the time period of most frequent and intense leopard grouper feeding (Hobson 1968). Specimens were later transported to the Ecology Laboratory of the Centro Interdisciplinario de Ciencias Marinas, Instituto Politécnico Nacional (CICIMAR-IPN). The total length (TL) $( \pm 0.5 \mathrm{~mm}$ precision) and total weight (TW) $( \pm$ $0.001 \mathrm{~g}$ precision) of each specimen were recorded. Sex was determined by direct observation of the gonad, and this was later corroborated using the standard histological technique to determine cellular types, annual variability, and gonad developmental stages (Nikolsky 1963, EstradaGodínez et al. 2011, Pérez-Olivas et al. 2018). A chisquared test was used to test whether the observed female $\div$ male ratio deviated from the expected $1 \div 1$ proportion, with 0.05 significance level.

Preys were identified to the lowest possible taxon following specialized keys. For fishes in a low state of digestion, we used keys by Miller and Lea (1972), Whitehead (1985), Fischer et al. (1995), Allen and Robertson (1998), and Thomson et al. (2000). For fishes in an advanced state of digestion, we used keys by Clothier and Baxter (unpublished*), and Lowry (2011). For cephalopods, we used keys by Iverson and Pinkas (1971),

* Taylor N. 2008. Impacts of intense fishing of groupers (Serranidae) as top key stone predators and the subsequent effects on the supporting reef ecosystem of Utila Island: Catch assessment and stomach content analysis. Master's thesis, University of Glamorgan. Trefforest, Wales, UK. 
Wolff (1984), and Clarke (1986). For crustaceans, we used the key by Brusca (1980).

Data of individuals collected in the study area were categorized by sex (male or female) and size (small $=$ $21-36 \mathrm{~cm}$, medium $=36.5-51 \mathrm{~cm}$, or large $=51.5-70$ $\mathrm{cm})$, as no juveniles were captured. Sizes were classified according to Sturge's rule (Daniel 1997) and based on the histological analysis performed by Pérez-Olivas et al. (2018). We used monthly mean values of sea surface temperature to determine the seasons, based on satellite images in Hierarchical Data Format obtained from the MODIS-AQUA sensor with $1.1 \mathrm{~km}$ spatial resolution at the nadir. Spring comprised the months of April to June 2014 and 2015; summer comprised the months of July to September 2014, autumn comprised the months of October to December 2014, and winter comprised the months of January to March 2014 and 2015 (Fig. 2).

A species accumulation curve was constructed to determine the representativity of analysed stomachs (EstimateS ${ }^{* *}$ ), based on the value of the Shannon-Wiener $\left(H^{\prime}\right)$ diversity index for each stomach. The coefficient of variation $(\mathrm{CV})$ was calculated to obtain a quantitative estimate of the number of stomachs that would be adequate and representative of the general diet and of the diet by category. If the $\mathrm{CV}$ was equal to or less than $5 \%(0.05)$ the number of stomachs examined was considered adequate to represent the diet (Jiménez-Valverde and Hortal 2003, Moreno-Sánchez et al. 2016).

In order to compare the presently reported study, diet was analysed using three methods for each prey taxon following Hyslop (1980):

The percentage frequency of occurrence $(\% \mathrm{FO})$, referred as the frequency of occurrence of prey items within the total number of stomachs with food.

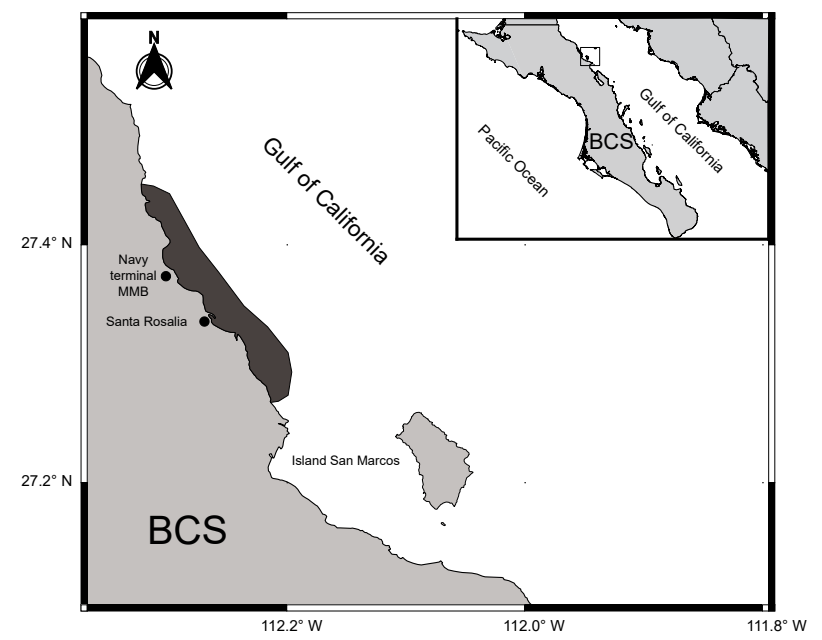

Fig. 1. The shaded area shows the Mycteroperca rosacea sampling location, in the Santa Rosalía region, BCS, Mexico
The numerical percentage of abundance $(\% N)$, calculated as the prey item abundance within the total number of prey items identified in the total number of stomachs with food.

The gravimetric percentage $(\% W)$ calculated as the wet weight of prey items found within the total wet weight of stomachs with food.

The percentage frequency of occurrence can be calculated using the following formula

$\% \mathrm{FO}=\left(\frac{\text { No. of stomachs including a prey item }}{\text { No. of stomachs with food }}\right) \times 100$

The numerical percentage of abundance can be calculated using the following formula

$$
\% N=\left(\frac{\text { No. of prey items }}{\text { Total No. of prey items }}\right) \times 100
$$

The gravimetric percentage can be calculated using the following formula

$$
=\left(\frac{\text { Weight of prey items }}{\text { Total weight. of prey item }}\right) \times 100
$$

The hierarchization of food items was established using the Index of Relative Importance (IRI) of Pinkas et al. (1971), which provided an optimal balance of the three methods (below)

The values of IRI were expressed in percentage to facilitate the comparison with others studies (Cortés et al. 1996):

$$
\mathrm{IRI}=(\% \mathrm{~N}+\% \mathrm{~W}) \times \% \mathrm{FO}
$$

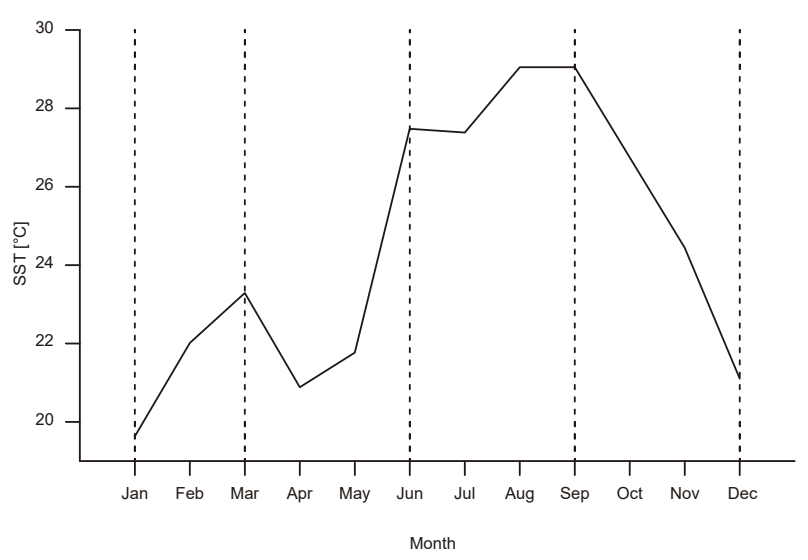

Fig. 2. Monthly records of sea surface temperature (2014 2015) during winter, spring, summer, and autumn in central Gulf of California

\footnotetext{
* Clothier C.R., Baxter J.L. 1969. Vertebral characters of some Californian fishes with notes on other eastern Pacific species. Unpublished manuscript. State of California, the Resources Agency, Department of Fish and Game. [Originally intended for Fish Bulletin.]

" http://viceroy.eeb.uconn.edu/Estimates
} 


$$
\% \mathrm{IRI}_{i}=\frac{100 \mathrm{IRI}_{i}}{\sum_{i=1}^{n} \mathrm{IRI}_{I}}
$$

The prey-specific index of relative importance (\%PSIRI) was also used; this is a mathematical correction of the IRI index (Brown et al. 2012) that contrasts the quantitative results obtained with the IRI. This index was calculated as

$$
\% \mathrm{PSIRI}_{i}=\frac{\% \mathrm{FO}_{i} \times\left(\% \mathrm{PN}_{i}+\% \mathrm{PW}_{i}\right)}{2}
$$

where \%PSIRI is prey-specific index of relative importance, $\% \mathrm{FO}$ is percent frequency of occurrence, $\% \mathrm{PN}$ is percent prey-specific number, and $\% \mathrm{PW}$ is percent prey-specific weight.

Diet breadth was calculated using Levin's standardized index $\left(B_{i}\right)$ (Hurlbert 1978). This index was constructed from the standardized number of prey. If this index takes on values close to zero it indicates a specialist feeding strategy. If it takes on values close to one it indicates a generalist feeding strategy (Krebs 1989). This index was calculated using the following equation

$$
B_{i}=\frac{1}{n-1}\left(\frac{1}{\sum_{j} p_{i j}^{2}}-1\right)
$$

where $B_{i}$ is the niche width, $\sum_{j} p_{i j}^{2}$ is the proportion of the $j^{\text {th }}$ item in the diet of the $i^{\text {th }}$ predator, and $n$ is the total number of items.

To interpret the feeding strategy of the leopard grouper and establish population or individual feeding patterns, we used Costello's analysis (1990) modified by Amundsen et al. (1996).

To evaluate significant differences in the feeding habits of leopard grouper according to sex, size, and season, as well as size-sex interactions, we applied a multivariate analysis of variance (PERMANOVA) with 1000 permutations. This analysis was performed through the Adonis function in the Vegan 2.2-1 library (Oksanen et al. 2015) using the R 3.0.1 platform*, with a $95 \%$ confidence level.

\section{RESULTS}

Captured leopard grouper, Mycteroperca rosacea, ranged from 21 to $74 \mathrm{~cm}$ TL and weighed between 120 and $5820 \mathrm{~g}$. The sexual proportion $(q \div 3)$ was $2 \div 1$ (Chi-square test $\chi^{2}=19.18 ; P<0.05$ ) (Pérez-Olivas et al. 2018). Of 341 stomachs obtained, 309 contained food (90\%) and 32 were empty (10\%). According to the CV of the accumulated species curve, the general sample size and sample size by category (sex, size, and season) were adequate to describe this species' diet (Table 1).

General diet. A total of 28 prey items were identified in the 309 analysed stomachs, including 22 fish species, 5 crustacean species, and 1 mollusc species. According to

\footnotetext{
*http://CRAN.R-project.org/
}

Table 1

Minimum sample size of Mycteroperca rosacea from central Gulf of California, Mexico, determined for all samples and by sex, size, and season

\begin{tabular}{cccc}
\hline Category & $N_{\mathrm{s}}$ & $N_{\mathrm{sm}}$ & $\mathrm{CV}$ \\
\hline General & 309 & 170 & 0.05 \\
Females & 193 & 98 & 0.05 \\
Males & 116 & 67 & 0.05 \\
Small & 146 & 92 & 0.05 \\
Medium & 132 & 82 & 0.05 \\
Large & 31 & 27 & 0.05 \\
Winter & 45 & 25 & 0.05 \\
Spring & 177 & 85 & 0.05 \\
Summer & 19 & 17 & 0.05 \\
Autumn & 68 & 43 & 0.05 \\
\hline
\end{tabular}

$N_{\mathrm{s}}=$ number of stomachs analysed, $N_{\mathrm{sm}}=$ minimum number of stomachs by category, $\mathrm{CV}=$ coefficient of variation for the respective sample size.

the \%IRI the prey with greatest relative importance in the diet were the euphausiid Nyctiphanes simplex (65.5\%), and fishes Sardinops sagax (20.9\%), Chromis atrilobata Gill, 1862 (3.9\%), Stegastes rectifraenum (Gill, 1862) (2.5\%), and Microlepidotus inornatus Gill, 1862 (2.4\%), comprising as a whole $95 \%$ (Table 2). The \%PSIRI also highlighted the importance of the already mentioned prey but with different percentages of contribution to the diet: $N$. simplex $(27.4 \%)$, S. sagax (25.1\%), C. atrilobata (8.5\%), S. rectifraenum (7.3\%), Abudefduf troschelii (Gill, 1862) (6.8\%), and Harengula thrissina (6.2\%) represented $80 \%$ of the trophic spectrum. It should be noted that other prey that were not included in the \%IRI were incorporated in the \%PSIRI, such as Ophioblennius steindachneri Jordan et Evermann, 1898, Medialuna californiensis (Steindachner, 1876), Caulolatilus princeps (Jenyns, 1840), Engraulis spp., H. thrissina, and Anchoa spp., comprising approximately $2 \%$ each (Table 2 ).

Other prey fishes identified to the species level included Acanthistius sebastoides (Castelnau, 1861); Stegastes acapulcoensis (Fowler, 1944); Paralabrax maculatofasciatus (Steindachner, 1868); and Triphoturus mexicanus (Gilbert, 1890).

Diet by sex. A total of 19 prey items were identified in the stomachs of 116 male leopard grouper. The \%IRI indicated that the most important prey were the euphausiid N. simplex $(76 \%)$ and several fish species that represented $20 \%$ of the diet (S. sagax, S. rectifraenum, C. atrilobata, $M$. inornatus, and $A$. troschelii). A total of 23 prey items were identified in the stomachs of 193 female leopard grouper. The most important were $N$. simplex (54\%), S. sagax (32\%), C. atrilobata (4\%), and A. troschelii (4\%) (Fig. 3). The \%PSIRI showed a different proportion from that obtained with the \%IRI. According to the \%PSIRI the most important prey items in the male diet were $N$. simplex (37\%), S. sagax (19\%), S. rectifraenum (10\%), C. atrilobata (7\%), M. inornatus (6\%), and $A$. troschelii (4\%). The most important prey items in the female diet were $S$. sagax (30\%), N. simplex $(22 \%)$, C. atrilobata $(10 \%)$, A. troschelii $(8 \%)$, M. inornatus (6\%), and H. thrissina (7\%; Fig. 3). 
$\frac{\text { vै }}{\frac{0}{2}}$

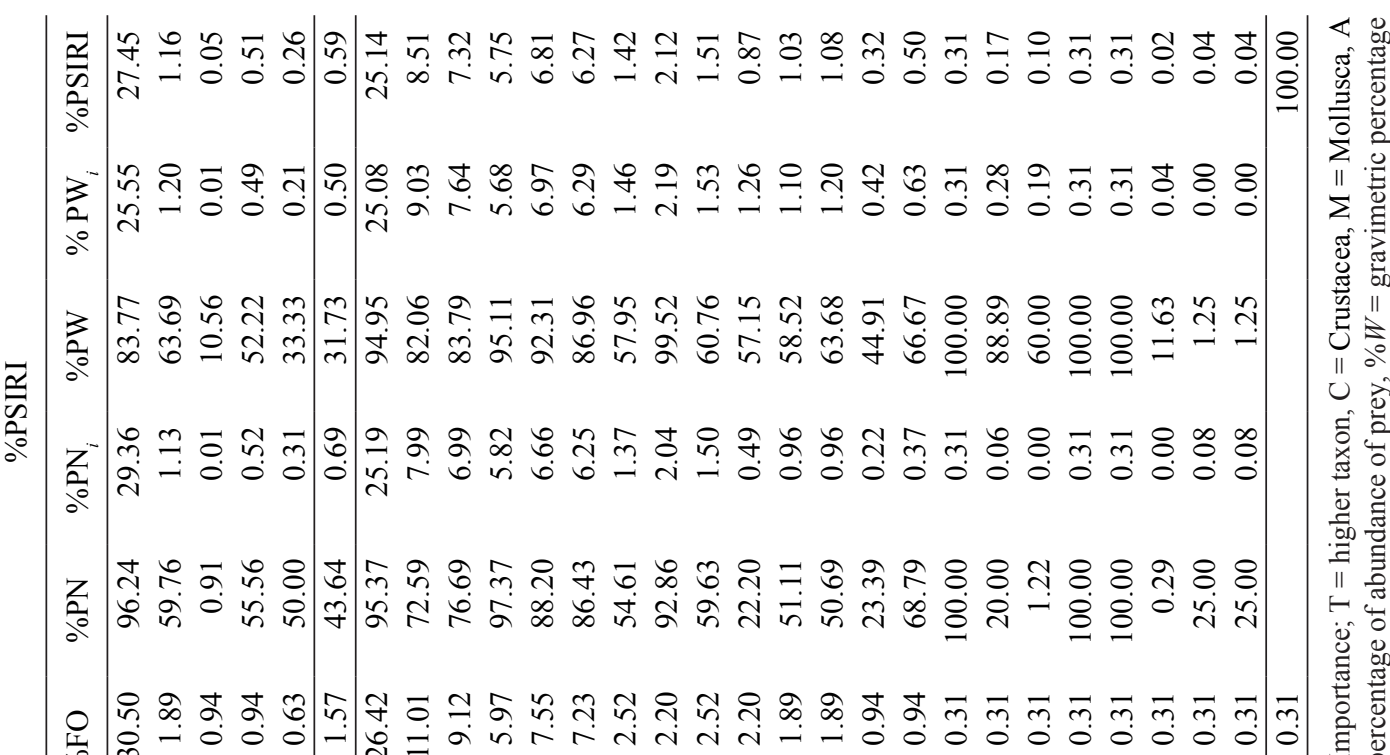

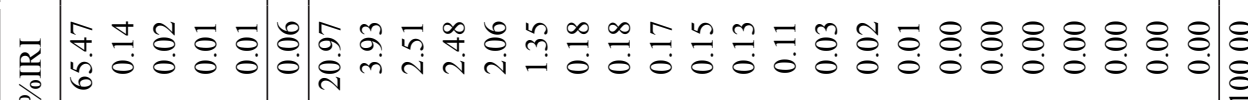

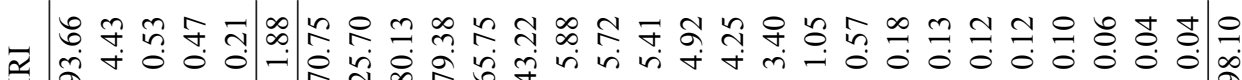

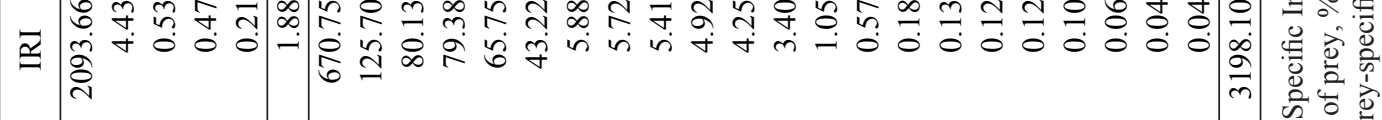

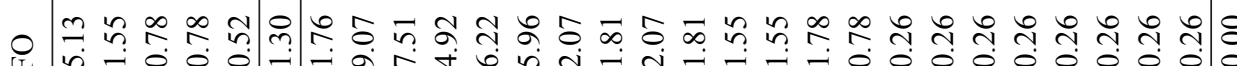
造

定

夈

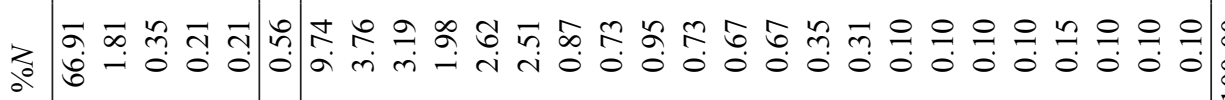
仓े

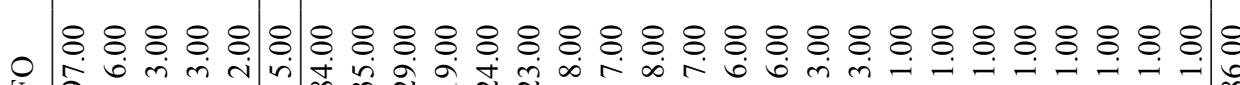

金方

i

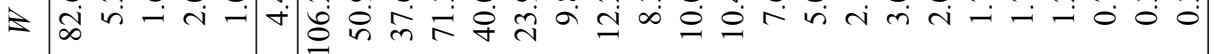
2. $\frac{0}{>}$

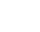

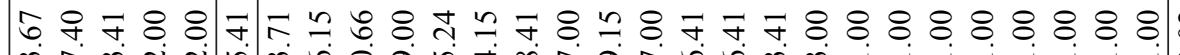
ช 守 
Diet by size. The preys with greatest relative importance (\%IRI) in the 146 small-sized leopard grouper analysed were the euphausiid $N$. simplex $(78.6 \%)$ and two fish species, $S$. sagax and $C$. atrilobata, which contributed $21 \%$ to the overall diet. A total of 132 medium-sized and 21 large-sized leopard grouper were analysed. These two sizes consumed a lower proportion of $N$. simplex ( $48 \%$ and $45 \%$, respectively) than of fish (51\% and 54\%, respectively). Fishes consumed included S. sagax, M. inornatus, C. atrilobata, A. troschelii, and $S$. rectifraenum (Fig. 3). The \%PSIRI resulted in a change in prey proportion compared with the \%IRI. The euphausiid $N$. simplex comprised $37 \%$ of the small-sized leopard grouper diet, whereas fish comprised 60\%. Fish contributed $77 \%$ of medium- and $80 \%$ of large-sized leopard grouper diets and euphausiids contributed 19 and $17 \%$, respectively (Fig. 3).

Diet by season. A total of 177 leopard grouper stomachs were obtained in spring (2014 and 2015). According to the \%IRI, the preys that contributed most to the diet were the euphausiid $N$. simplex $(75.9 \%)$ and the fishes S. rectifraenum (5.6\%) and C. atrilobata (5.2\%). A total of 19 stomachs containing food were obtained in summer 2014; the most dominant prey according to the \%IRI were fishes, represented by $S$. sagax (37.1\%), O. steindachneri (37.1\%), and C. atrilobata (10.4\%). A total of 68 stomachs were obtained in autumn 2014; the dominant prey according to the \%IRI was the fish $S$. sagax, with over $96 \%$ of the total diet spectrum. A total of 45 stomachs were obtained in winter (2014 and 2015). During this time
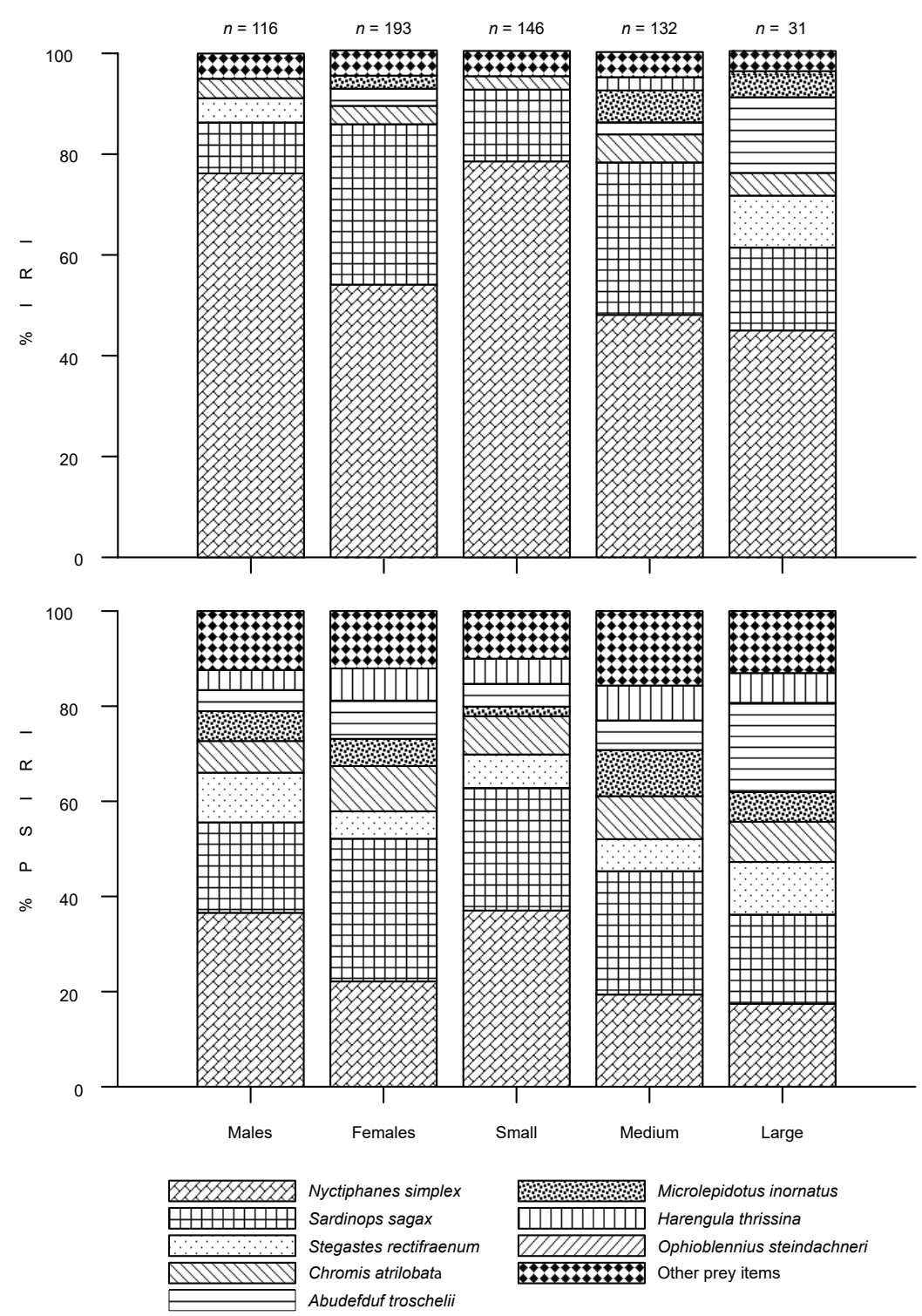

Fig. 3. Variation of prey species consumed by Mycteroperca rosacea, in central Gulf of California, Mexico, determined with the Index of Relative Importance (\%IRI) and Prey-Specific Index of Relative Importance (\%PSIRI), as a function of sex and size 
of year, the dominant prey in the diet were the fish $S$. sagax (88.1\% IRI) and the euphausiid N. simplex (9.8\%) (Fig. 4).

Based on the \%PSIRI, the dominant preys in spring were the euphausiid $N$. simplex (40\%) and the fishes S. rectifraenum (10.2\%), A. troschelii (10\%), M. inornatus (9.8\%), and C. atrilobata (9.8\%). The most important preys in summer were the fish $S$. sagax $(23.6 \%)$, O. steindachneri (23.6\%), C. atrilobata (12.3\%), and M. californiensis $(10.5 \%)$. The most important prey in autumn were the fish S. sagax (67.3\%), C. atrilobata (7.9\%), and H. thrissina (5.2\%), and the euphausiid $N$. simplex (5.8\%). The dominant preys in winter were the fish $S$. sagax (61\%) and the euphausiid N. simplex (19.7\%) (Fig. 4).

Diet breadth and feeding strategy. The trophic strategy of the leopard grouper was that of a specialist predator
$\left(B_{i}=0.04\right)$. This was observed for males and females $\left(B_{i}=\right.$ 0.06 , respectively) and for the three size intervals $\left(B_{i}=0.04\right.$, $B_{i}=0.08$, and $\left.B_{i}=0.14\right)$, as well as during the four seasons (spring: $B_{i}=0.19$, summer: $B_{i}=0.47$, autumn: $B_{i}=0.10$, and winter: $B_{i}=0.13$ ). The Costello graph confirmed that the leopard grouper had a narrow trophic width; that is, its diet comprised a small number of very frequent and abundant prey (Fig. 5A). However, the species that dominated the leopard grouper diet changed according to sex, size, and season. Males fed mainly on N. simplex, S. sagax, and C. atrilobata, whereas females fed on $S$. sagax, N. simplex, A. troschelii, and C. atrilobata (Fig. 5B, 5C). Although the different-size fish fed on mostly the same species, the proportion changed depending on the size. For example, small and medium fish consumed mainly coastal pelagic prey $(S$. sagax and
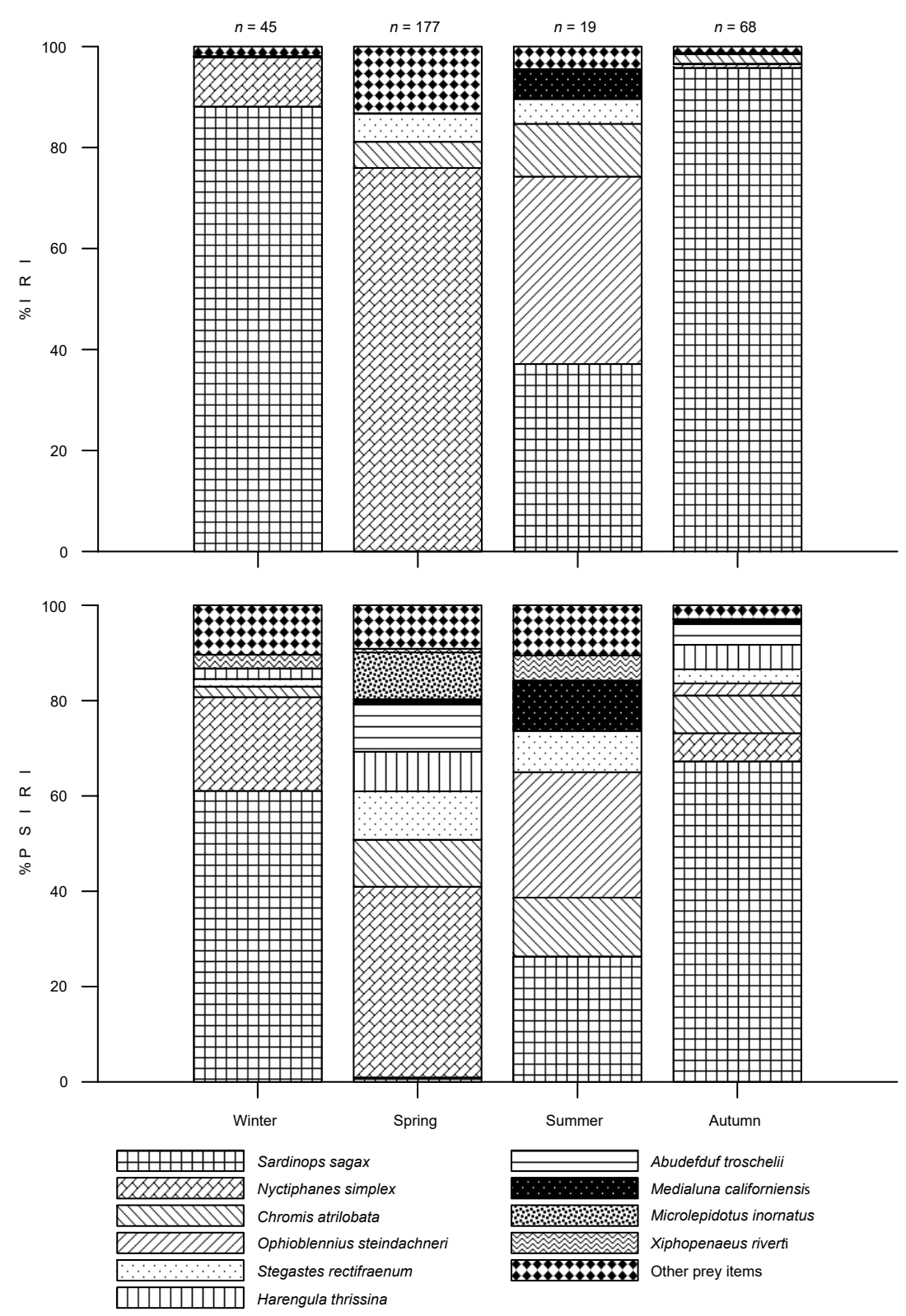

Fig. 4. Variation of prey species consumed by Mycteroperca rosacea, in central Gulf of California, Mexico, calculated with the Index of Relative Importance (\%IRI) and Prey-Specific Index of Relative Importance (\%PSIRI) as a function of the season (winter, spring, summer, and autumn) 
$N$. simplex), whereas large sizes also consumed fishes such as A. troschelii and S. sagax, and the euphausiid N. simplex (Fig. $5 \mathrm{D}, 5 \mathrm{E}, 5 \mathrm{~F})$. The most important preys during the spring were the euphausiid $N$. simplex, and the fishes C. atrilobata and A. troschelii (Fig. 6A). The most important preys in summer were fishes $O$. steindachneri, S. sagax, and C. atrilobata (Fig. 6B). The most important prey in autumn were fishes S. sagax, H. thrissina, A. troschelii, and C. atrilobata, and the euphausiid N. simplex (Fig. 6C). The most important prey in winter were the euphausiid $N$. simplex and the fishes $S$. sagax, $S$. rectifraenum, $C$. atrilobata, and $H$. thrissina (Fig. 6D).

The PERMANOVA test highlighted differences in leopard grouper diet by sex $(F=4.04, P<0.05)$, size $(F$ $=4.33, P<0.05)$, and season $(F=24.32, P<0.05)$, but interactions sex-size $(F=1.55, P=0.11)$, sex-season $(F$ $=1.57, P=0.11)$, size-season $(F=1.56, P=0.09)$, and sex-size-season $(F=1.40, P=0.16)$ were not significant (Table 3).

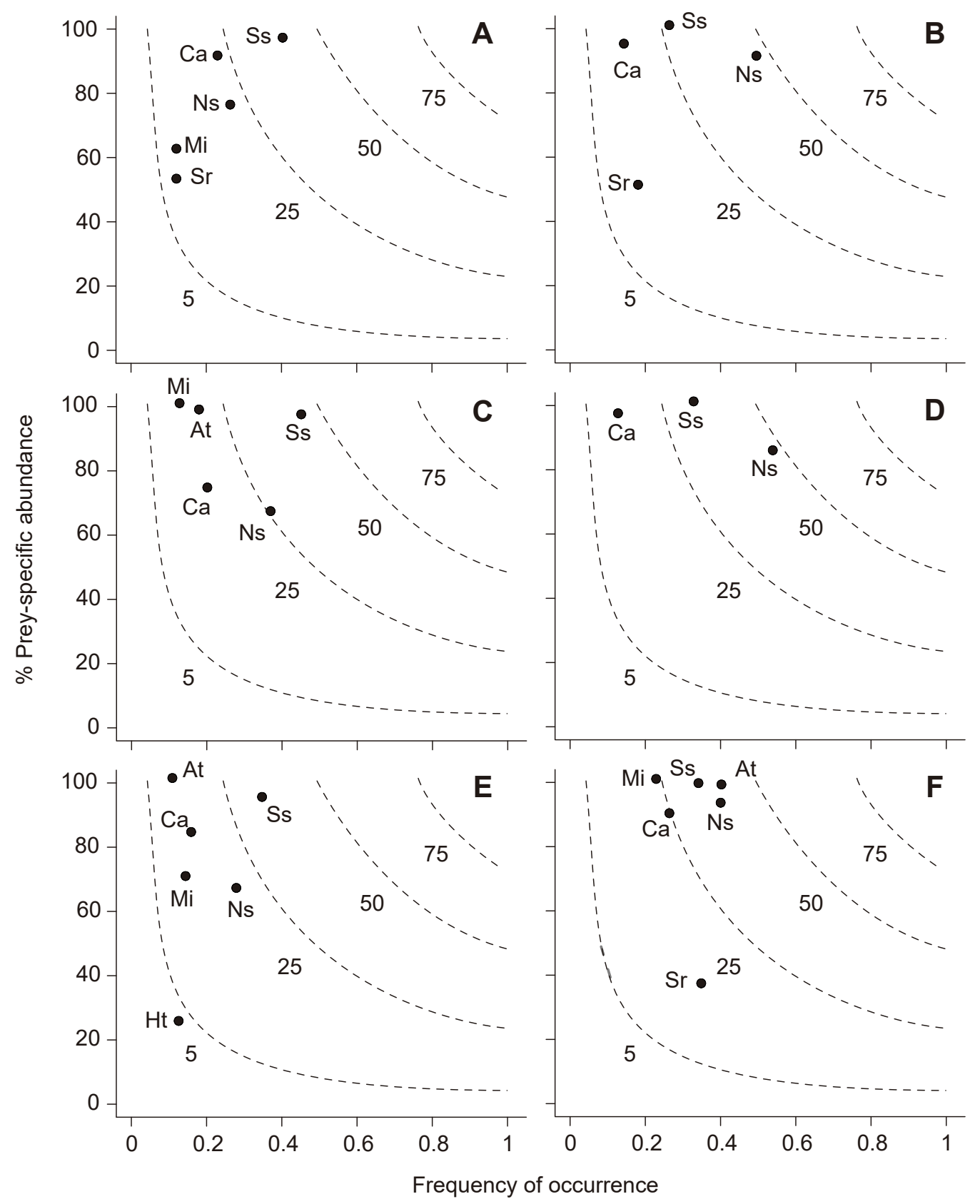

Fig. 5. Costello graph; Prey-specific abundance $(\% \mathrm{~N})$ of prey species by percentage frequency of occurrence $(\% \mathrm{FO})$ in the general diet of Mycteroperca rosacea, in central Gulf of California, Mexico; (A) general, (B) males, (C) females, (D) small, (E) medium, and (F) large; Ss = Sardinops sagax, $\mathrm{Ca}=$ Chromis atrilobata, Ns $=$ Nyctiphanes simplex, $\mathrm{Sr}=$ Stegastes rectifraenum, $\mathrm{Mi}=$ Microlepidotus inornatus, $\mathrm{At}=$ Abudefduf troschelii, $\mathrm{Ht}=$ Harengula thrissina, Os = Ophioblennius steindachneri 


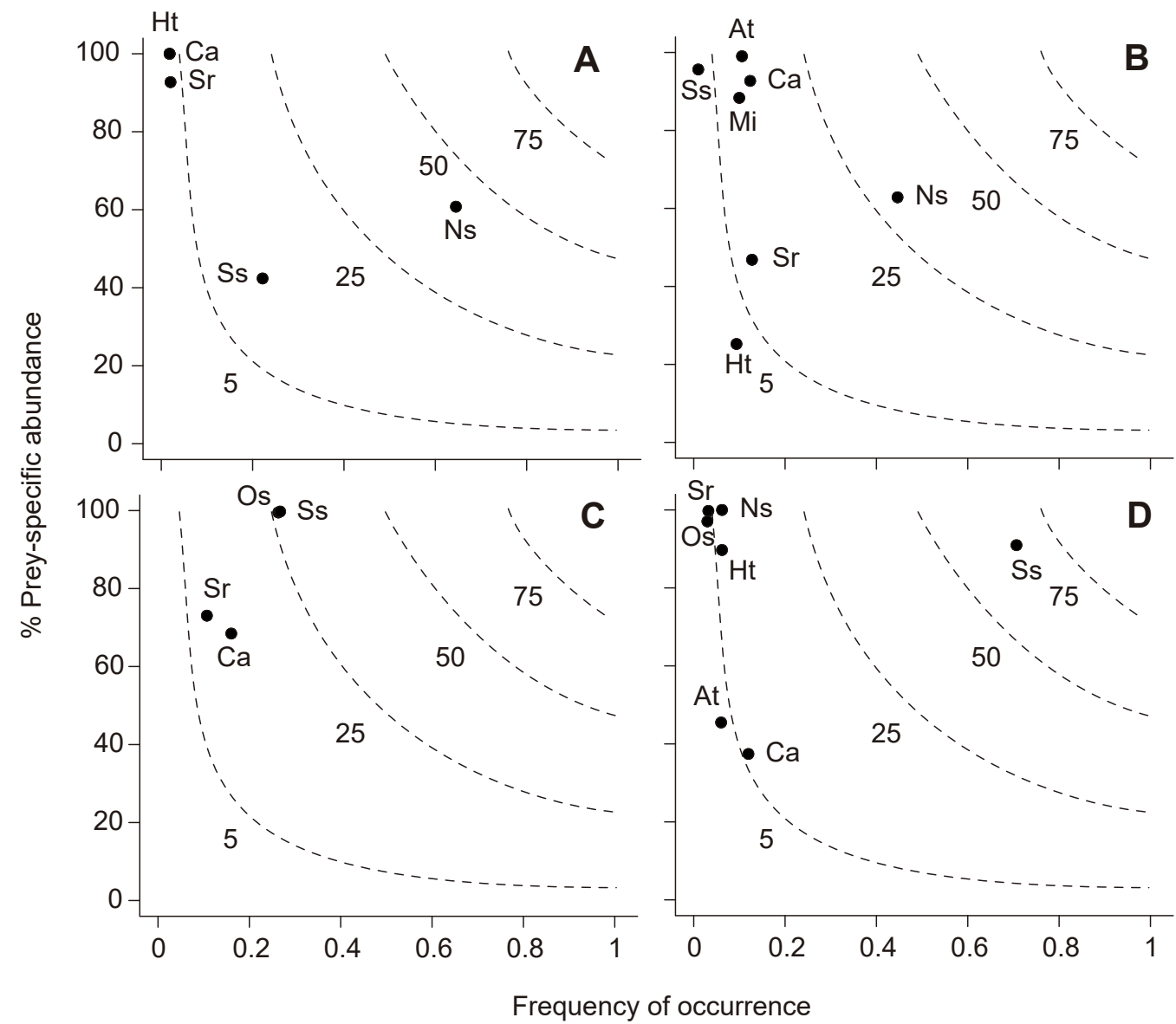

Fig. 6. Costello graph; Prey specific abundance $(\% \mathrm{~N})$ of prey species by percentage frequency of occurrence $(\% \mathrm{~F})$ in the diet of Mycteroperca rosacea, in central Gulf of California, Mexico, according to the season: winter (A), spring (B), summer (C), and autumn (D); Ss = Sardinops sagax, Ca = Chromis atrilobata, Ns = Nyctiphanes simplex, $\mathrm{Sr}=$ Stegastes rectifraenum, $\mathrm{Mi}=$ Microlepidotus inornatus, $\mathrm{At}=$ Abudefduf troschelii, $\mathrm{Ht}=$ Harengula thrissina, Os $=$ Ophioblennius steindachneri

Table 3 study focusing on the trophic behaviour of this fish used

Significance values for diet variance analyses (Permutational multivariate analysis of variance, PERMANOVA) between sexes, sizes, and seasons for Mycteroperca rosacea from central Gulf of California, Mexico

\begin{tabular}{lrrrc}
\hline \multicolumn{1}{c}{ Factor } & \multicolumn{1}{c}{$F$} & \multicolumn{1}{c}{$r$} & \multicolumn{1}{c}{$P$} & Significance \\
\hline Sex & 4.043 & 0.0119 & 0.02 & Yes \\
Size & 4.335 & 0.01276 & 0.002 & Yes \\
Season & 24.327 & 0.07159 & 0.001 & Yes \\
Sex-Size & 1.555 & 0.00458 & 0.104 & NO \\
Sex-Season & 1.5731 & 0.00463 & 0.114 & NO \\
Size-Season & 1.5691 & 0.00462 & 0.104 & NO \\
Sex-Size-Season & 1.4066 & 0.00414 & 0.156 & NO \\
\hline
\end{tabular}

$F=$ PERMANOVA test, $r=$ similarity between groups, $P=$ probability values.

\section{DISCUSSION}

Based on results obtained from the quantitative composite indices (\%IRI and \%PSIRI), the most important prey in the diet of Mycteroperca rosacea were pelagiccoastal organisms (euphausiid $N$. simplex and South American pilchard S. sagax). Hobson (1968) in a qualitative
\%IRI to establish that in the southern GC the leopard grouper diet was composed mainly of Pacific flatiron herring $H$. thrissina and demersal fish such as scombrids, haemulids, and pomacentrids. It should be emphasized that in the above-mentioned study crustaceans were considered incidental prey. Other papers (Parrish 1992, Thomson et al. 2000) as well as results obtained in the presently reported study suggest that the leopard grouper could integrate an important quantity of incidental prey into its diet, which constitutes clear evidence of this epinephelid's great trophic plasticity, which has already been reported for other species in the family (Randall 1998, Gómez et al. 1999, Zapata et al. 1999, Helfman et al. 2009).

The optimal foraging theory can be proposed as a model to explain the observed high consumption of incidental prey, as this theory posits that the behaviour of a predator during the selection and search for food is determined by the maximum amount of energy obtained and the minimum cost invested in prey capture (in this case, euphausiids), taking into account limiting factors such as competition, predation, and environmental variations. Such assumption is closely related to prey abundance and spatio-temporal variations in prey abundance, because the theory predicts that at low 
preferred prey abundance (in this case herring and other fish), the predator will tend to consume the most abundant food items at the time, reflecting the trophic plasticity of the predator and the availability and seasonal abundance of prey (Stephens and Krebs 1986, Gerking 1994).

We found changes in the diet according to sex using $\%$ IRI and \%PSIRI. The diet of female leopard grouper was composed mainly of fishes, whereas there was a greater proportion of euphausiids $N$. simplex in the male diet. These differences in diet could be reflecting the different rates of energetic demand for the two sexes. Females consumed more fish and would, therefore, obtain a greater quantity of energy per mass unit of consumed prey than male leopard groupers, who fed mainly on euphausiids, a prey with lower energetic quality (Thayer et al. 1973). It should also be noted that nutritional requirements could vary as a function of the different stages of the reproductive cycle. Estrada-Godínez et al. (2011) documented an increase in the protein, triglyceride, and cholesterol content in the liver, gonad, and muscle of $M$. rosacea during the different stages of gonad development, which reached maximum values during spawning, and a notable reduction during the resting period.

According to Bermejo Miramontes (unpublished*), who carried out a study on age and growth on the same specimens used in the present study, $M$. rosacea has medium longevity with relatively slow growth, reaching sizes between 21 and $74 \mathrm{~cm}$ TL, which correspond to ages between 1 and 15 years, in the area of Santa Rosalía. The age groups of 3 and 4 years were the most represented. The estimates from that study were lower than those reported by Díaz-Uribe et al. (2001) of between 29 and $97.5 \mathrm{~cm}$ TL, and of age groups between 1 and 21 years in La Paz Bay and adjacent BCS areas. Due to the fact that we did not obtain specimens measuring $>74 \mathrm{~cm}$ given the fishing gear used, our analysis was limited to a size spectrum that did not include juveniles or larger adults.

In this context, we detected trophic variations in the different sizes of leopard grouper. Small leopard grouper fed mainly on euphausiids $N$. simplex. Leopard grouper recruits had little hunting ability, as well as possible morphological limitations due to their small size, which could restrict the diet breadth and prey size (Winemiller 1989). Medium and large leopard grouper incorporated a wide diversity of prey into their diet, preferably fish. The trophic change in large leopard grouper could be attributed to their improved swimming ability and more developed and efficient search, hunt, and capture abilities, which are magnified by development and greater mandibular aperture (Hobson 1968, Werner 1977, Hoyle and Keast 1987, Wainwright 1987, Wainwright and Barton 1995).

It should be noted that as the leopard grouper has been reported to be a shallow-water crepuscular predator that is relatively inactive during the middle of the day and at night (Hobson 1968, Thomson et al. 2000), specimens were captured during the crepuscular period (05:00 to 08:00 $\mathrm{h}$ ), which is the time period of most frequent and intense feeding. This was confirmed with the present study, as of
341 analysed specimens, 309 (90\%) presented stomachs containing food. This resulted in the diet characterization reflecting the feeding habits during morning hours and not during the other important feeding time that occurs immediately after sunset (Thomson et al. 2000).

Size-dependent feeding behaviour has been reported for other epinephelids (Mullaney 1994, Giménez et al. 2001, Reñones et al. 2002, Linde et al. 2004, Condini et al. 2011, 2015, Artero et al. 2015). It should also be noted that the body shape of $M$. rosacea could play an important role in its feeding habits, because according to Gibran (2007) the genus Mycteroperca is characterized by a elongated and slim body that gives it high mobility within the water column and, therefore, greater preference for pelagic prey, such as clupeids (Hobson 1968, Parrish 1992), which was seen in this study with the great consumption of pilchard and euphausiids.

There were also variations in the leopard grouper diet with the seasons. The euphausiid $N$. simplex was consumed moderately during winter. There was a notable increase in consumption during spring when it became the dominant prey. Nyctiphanes simplex disappeared completely from the diet during the warmer months of summer, and it was consumed in low amounts during autumn. Nyctiphanes simplex is the most abundant euphausiid within the GC and is usually found in higher densities during winter (Brinton 1962, Brinton and Towsend 1980, Gómez-Gutiérrez 1996). This could explain the large contribution of $N$. simplex to the leopard grouper diet during winter and spring. Moreover, there is a welldefined distribution pattern that it presents during the cold season, as this species tends to migrate closer to the surface when the water column presents a homogeneous temperature $\leq 17^{\circ} \mathrm{C}$ (Gómez-Gutiérrez et al. 2010).

The pelagic fish $S$. sagax was recorded in the diet during three of the four seasons (winter, summer, and autumn). There is an intrusion of equatorial surface waters into the study area during the warmer months, which causes an increase in sea surface temperature and a decrease in chlorophyll concentration in the central GC (Alvarez Borrego and Schwartzlose 1979, Lavín and Marinone 2003). This causes pilchards to become concentrated in areas of high productivity, one of which is located around the large islands (Badan-Dagon et al. 1985, Santamaría del Ángel et al. 1994, Alvarez-Borrego 2008) that are considered important centres of species dispersal and of this prey in particular (Martínez-Zavala et al. 2010). We cannot rule out that pilchard consumed by leopard grouper in Santa Rosalía came from these areas of high primary productivity, which occur year-round. It is also possible that upwelling processes could occur in the warm season in waters adjacent to Santa Rosalía, congregating dense schools of pilchard (Roden 1964, Badan-Dagon et al. 1985, Cotero-Altamirano et al. 2015) and making this trophic resource available to leopard grouper.

Demersal fishes were present in stomach contents of leopard grouper year-round. It is probable that this type of trophic resource is available year-round for leopard grouper as they share the same habitat (Hobson 1968).

* Bermejo Miramontes, G. A. 2018. Edad, crecimiento y mortalidad de Mycteroperca rosacea (Streets,1877), en Santa Rosalia, Baja California Sur, México. Masters thesis, Centro Interdisciplinario de Ciencias Marinas, Instituto Politécnico Nacional. La Paz BCS, México. 
Although there were substantial trophic changes in the diet of leopard grouper over the seasons, it should be noted that the main prey, euphausiids and pilchard, were consumed when their abundances were highest in the central region of the GC (Brinton 1962, Cisneros-Mata et al. 1995).

PERMANOVA multivariate analyses are being increasingly employed in fish trophic ecology studies (Freitas et al. 2015, Pereira et al. 2015, Rosa et al. 2015) due to their statistical rigor (Anderson and Walsh 2013). This analysis indicated that there were significant differences in the diet of leopard grouper by sex, size, and season, but no significant interactions. Differences found could be the result, as was mentioned, of the seasonal availability of feeding resources, the different energetic requirements linked to sex and/or gonad developmental stages, as well as the hunting ability. In this sense leopard grouper was categorized as a specialist predator, since of the 28 species identified in its stomach contents, only five (N. simplex, S. sagax, C. atrilobata, M. inornatus, and $S$. rectifraenum) comprised over $90 \%$ of its diet. This strategy is not common among epinephelids (Parrish 1987, Bullock and Murphy 1994, St. John 1999, 2001, St. John et al. 2001); however, there are prior records of Epinephelus marginatus (Lowe, 1834) and Mycteroperca rubra (Bloch 1793) having this type of feeding behaviour (Linde et al. 2004, Aronov and Goren 2008, Condini et al. 2011).

It should be emphasized that until now no feeding strategy characterization has been carried out for M. rosacea, but according to results obtained using the two quantitative composite indices it was evident that the diet comprised a reduced number of dominant species, notably $S$. sagax and $N$. simplex. This trophic behaviour could be influenced by the great availability and abundance of these two prey species in the study area. The total mean biomass of $N$. simplex has been calculated at $5098 \mathrm{t}$, whereas for pilchard it has been calculated at $50000 \mathrm{t}$; these two species form great coastal aggregations in the GC (Anonymous 2012, Martínez Gómez unpublished*).

The specialist feeding strategy was consistent over the different categories; however, based on the Costello analysis, it was evident that the different categories did not feed simultaneously on these resources, and there was alternation in the consumption of the different prey according to sex, size, and season (Figs. 5 and 6), which allows an efficient distribution of feeding resources, and, therefore, a reduction in intraspecific competition (Gerking 1994).

The comparison of quantitative results obtained with the \%IRI and \%PSIRI showed that in general as well as by category (sex, size, and seasons), leopard grouper fed on the same prey species, although the proportion found of each species in the diet differed according to the index used. We consider that this difference in proportions could be due to the fact that the \%PSIRI algorithm uses a mean of the prey importance by number and weight with respect to the number of stomachs in which those items were recorded, contrary to the \%IRI, in which the importance of prey species is a function of the total number of stomachs, which results in an overestimation of prey (Hyslop 1980, Brown et al. 2012).
This fact was evidenced directly when contrasting and comparing the \%IRI and \%PSIRI graphs (Fig. 3 and 4). Based on this we suggest that in studies of feeding habit characterization the use of the \%PSIRI provides more trustworthy and robust information. We, therefore, provide an $\mathrm{R}$ routine that can help carry out its calculation simply. Finally, it should be pointed out that due to the proposal by Pinkas et al. (1971), \%IRI index has been used in a large number of studies on the characterization of the trophic spectrum of fish species. This tool is still efficient and useful, especially regarding the standardization of information collected over more than four decades, which is no doubt highly relevant for comparison purposes.

From the results obtained in this study, we determined that in Santa Rosalía BCS, the leopard grouper, Mycteroperca rosacea, is a carnivorous predator whose prey can be coastal fishes or invertebrates distributed near the rocky bottom or in the water column. We also noted that despite the narrow trophic niche observed, there was a high degree of intraspecific variation in the composition and abundance of the leopard grouper prey species, minimizing competition for food.

\section{ACKNOWLEDGEMENTS}

The authors are grateful for economic support provided by the projects SIP-IPN (20160319) and CONACyT Problemas Nacionales (project 248708). XGMS and LAAC are grateful for support received through COFAAIPN and EDI-IPN. EME and OES are grateful for economic support through the program "Cátedra CONACyT, proyecto 2137, FACIMAR-UAS. MSIA thanks the IPN and CONACyT for providing a Doctoral Grant.

\section{REFERENCES}

Allen G.R., Robertson D.R. 1998. Peces del Pacífico Oriental Tropical. Comisión Nacional para el Conocimiento y Uso de la Biodiversidad, CEMEX, S.A. y Agrupación Sierra Madre, SC. México DF, México.

Alvarez-Borrego S. 2008. [2] Oceanografía de la región de las grandes islas. Pp. 45-65. In: Danemann G.D., Ezcurra E. (eds.) Bahía de los Ángeles: Recursos naturales y comunidad, línea base 2007. Secretaría de Medio Ambiente y Recursos Naturales, México DF, Mexico; Instituto Nacional de Ecología, México DF, Mexico; Pronatura Norosete AC, Ensenada, BC, Mexico; San Diego Natural History Museum, San Diego CA, USA.

Alvarez Borrego S., Schwartzlose R.A. 1979. Water masses of the Gulf of California. Ciencias Marinas 6 (1-2): 43-63. DOI: $10.7773 / \mathrm{cm} . v 6 i 1.350$

Amezaga Herrán R. 1988. Análisis de contenidos estomacales en peces. Revisión bibliográfica de los objetivos y la metodología. Instituto Español de Oceanografia, Informes técnicos No. 63: 3-74.

Amundsen P.-A., Gabler H.-M., Staldvik F.J. 1996. A new approach to graphical analysis of feeding strategy

* Martínez Gómez S. 2009. Producción de biomasa de Nyctiphanes simplex (Crustácea: Euphausiacea) en el Golfo de California, México. Master's thesis, Centro Interdisciplinario de Ciencias Marinas, Instituto Politécnico Nacional, La Paz Baja California Sur, Mexico. 
from stomach contents data-Modification of the Costello (1990) method. Journal of Fish Biology 48 (4): 607-614. DOI: 10.1111/j.1095-8649.1996.tb01455.x

Anderson M.J., Walsh D.C. 2013. PERMANOVA, ANOSIM, and the Mantel test in the face of heterogeneous dispersions: What null hypothesis are you testing. Ecological Monographs 83 (4): 557-574. DOI: $10.1890 / 12-2010.1$

Anonymous 2012. Anuario estadístico de Acuacultura y Pesca 2012. Comisión Nacional de Acuacultura y Pesca, Gobierno de México, México, DF, Mexico. https://www.gob.mx/conapesca/documentos/anuarioestadistico-de-acuacultura-y-pesca

Anonymous 2013. Anuario estadístico de Acuacultura y Pesca 2013. Comisión Nacional de Acuacultura y Pesca, Gobierno de México, México, DF, Mexico. https://www.gob.mx/conapesca/documentos/anuarioestadistico-de-acuacultura-y-pesca

Aronov A., Goren M. 2008. Ecology of mottled grouper (Mycteroperca rubra) in the eastern Mediterranean. Electronic Journal of Ichthyology 2: 43-55.

Artero C., Koenig C.C., Richard P., Berzins R., Guillou G., Bouchon C., Lampert L. 2015. Ontogenetic dietary and habitat shifts in goliath grouper Epinephelus itajara from French Guiana. Endangered Species Research 27 (2): 275-287. DOI: 10.3354/esr00661

Badan-Dangon A., Koblinsky C.J., Baumgartner T. 1985. Spring and summer in the Gulf of California: Observations of surface thermal pattern. Oceanologica Acta 8 (1): 13-22.

Brinton E. 1962. The distribution of Pacific euphausiids. Bulletin of the Scripps Institution of Oceanography 8 (2): 21-270.

Brinton E., Townsend A. 1980. Euphausiids in the Gulf of California-The 1957 cruises. California Cooperative Oceanic Fisheries Investigations Report 21: 211-236.

Brown S.C., Bizzarro J.J., Cailliet G.M., Ebert D.A. 2012. Breaking with tradition: Redefining measures for diet description with a case study of the Aleutian skate Bathyraja aleutica (Gilbert 1896). Environmental Biology of Fishes 95 (1): 3-20. DOI: 10.1007/s10641011-9959-z

Brulé T., Puerto-Novelo E., Pérez-Díaz E., Renán X. 2005. Diet composition of juvenile black grouper (Mycteroperca bonaci) from coastal nursery areas of the Yucatán Peninsula, Mexico. Bulletin of Marine Science 77 (3): 441-452.

Brusca R.C. 1980. Common intertidal invertebrates of the Gulf of California. 2nd edn. University of Arizona Press, Tucson AZ, USA.

Bullock L.H., Murphy M.D. 1994. Aspects of the life history of the yellowmouth grouper, Mycteroperca interstitialis, in the eastern Gulf of Mexico. Bulletin of Marine Science 55 (1): 30-45.

Cisneros-Mata M.A., Nevárez-Martínez M.O., Hammann M.G. 1995. The rise and fall of the Pacific sardine, Sardinops sagax caeruleus Girard, in the Gulf of California, México. California Cooperative Oceanic Fisheries Investigations, Reports 36: 136-143.
Clarke M.R. 1986. A handbook for the identification of cephalopod beaks. Clarendon Press. Oxford, UK.

Condini M.V., Seyboth E., Vieira J.P., García A.M. 2011. Diet and feeding strategy of the dusky grouper Mycteroperca marginata (Actinopterygii: Epinephelidae) in a man-made rocky habitat in southern Brazil. Neotropical Ichthyology 9 (1): 161168. DOI: $10.1590 /$ S1679-62252011005000006

Condini M.V., Hoeinghaus D.J., Garcia A.M. 2015. Trophic ecology of dusky grouper Epinephelus marginatus (Actinopterygii, Epinephelidae) in littoral and neritic habitats of southern Brazil as elucidated by stomach contents and stable isotope analyses. Hydrobiologia $\mathbf{7 4 3}$ (1): 109-125. DOI: 10.1007/s10750-014-2016-0

Cortés E. 1997. A critical review of methods of studying fish feeding based on analysis of stomach contents: Application to elasmobranch fishes. Canadian Journal of Fisheries and Aquatic Sciences 54 (3): 726-738. DOI: $10.1139 / \mathrm{f} 96-316$

Costello M.J. 1990. Predator feeding strategy and prey importance: A new graphical analysis. Journal of Fish Biology 36 (2): 261-263. DOI: 10.1111/j.10958649.1990.tb05601.x

Cotero-Altamirano C.E., Valles-Ríos H., Venegas B. 2015. Biología reproductiva de la sardina del Pacífico Sardinops sagax de la costa occidental de Baja California, México. Ciencia Pesquera 23 (2): 25-43.

Craig M.T., Pondella D.J.II, Franck J.P.C., Hafner J.C. 2001. On the status of the serranid fish genus Epinephelus: Evidence for paraphyly based upon $16 \mathrm{~S}$ rDNA sequence. Molecular Phylogenetics and Evolution 19 (1): 121-130. DOI: 10.1006/mpev.2000.0913

Daniel W.W. 1997. Bioestadística. Base para el análisis de las ciencias de la salud. Limusa, México DF, Mexico.

Díaz-Uribe J.G., Elorduy-Garay J.F., GonzálezValdovinos M.T. 2001. Age and growth of the leopard grouper, Mycteroperca rosacea, in the southern Gulf of California, México. Pacific Science 55 (2): 171182. DOI: $10.1353 /$ psc.2001.0012

Dierking J., Williams I.D., Walsh W.J. 2009. Diet composition and prey selection of the introduced grouper species peacock hind (Cephalopholis argus) in Hawaii. Fishery Bulletin 107 (4): 464-476.

Erisman B., Craig M.T. 2018. Mycteroperca rosacea. The IUCN Red List of Threatened Species 2018: e.T14053A100466656. [Downloaded on 13 January 2019.] DOI: 10.2305/IUCN.UK.2018-2.RLTS.T140 53A100466656.en

Estrada-Godínez J.A., Maldonado-García M., GraciaLópez V., Carrillo M. 2011. Reproductive cycle of the leopard grouper Mycteroperca rosacea in La Paz Bay, México. Ciclo reproductivo de la cabrilla sardinera Mycteroperca rosacea enla bahía de La Paz, México. Ciencias Marinas 37 (4): 425-441.

Fischer W., Krupp F., Schneider W., Sommer C., Carpenter K.E., Niem V.H. 1995. Guía FAO para la identificación de peces para los fines de pesca. Pacífico Centro-Oriental. Vol. II and III. Vertebrados, Parts 1-2, 647-1813. 
Freitas M.O., Abilhoa V., Giglio V.J., Hostim-Silva M., de Moura R.L., Francini-Filho R.B., Minte-Vera C.V. 2015. Diet and reproduction of the goliath grouper, Epinephelus itajara (Actinopterygii: Perciformes: Serranidae), in eastern Brazil. Acta Ichthyolgica et Piscatoria 45 (1): 1-11. DOI: 10.3750/AIP2015.45.1.01

Gerking S.D. 1994. Feeding ecology of fish. Academic Press, San Diego, New York, Boston, London, Sydney, Tokio, Toronto. DOI: 10.1016/C2009-0-03283-8

Gibran F.Z. 2007. Activity, habitat use, feeding behavior, and diet of four sympatric species of Serranidae (Actinopterygii: Perciformes) in southeastern Brazil. Neotropical Ichthyology 5 (3): 387-398. DOI: 10.1590/S1679-62252007000300018

Giménez E., Anderes B., Moreno V., Burgos R. 2001. Aspectos de la conducta alimentaria del mero (Epinephelus morio) del Banco de Campeche. Ciencia Pesquera 2001 (14): 165-170.

Goeden G.B. 1982. Intensive fishing and a 'keystone' predator species: Ingredients for community instability. Biological Conservation 22 (4): 273-281. DOI: 10.1016/0006-3207(82)90022-2

Gómez C.G.O., Zapata P.L.A., FrankeA.R., Ramos T.G.E. 1999. Hábitos alimentarios de Epinephelus acanthistius y notas de otros peces serránidos capturados en el parque nacional natural de Gorgona, Pacífico colombiano. Boletín de Investigaciones Marinas y Costeras 28: 43-60. DOI: 10.25268/bimc.invemar.1999.28.0.320

Gómez-Gutiérrez J. 1996. Ecology of early larval development of Nyctiphanes simplex Hansen (Euphausiacea) off the southwest coast of Baja California, México. Bulletin of Marine Science 58 (1): 131-146.

Gómez-Gutiérrez J., Tremblay N., Martínez-Gómez S., Robinson C.J., Del Angel-Rodríguez J., RodríguezJaramillo C., Zavala-Hernández C. 2010. Biology of the subtropical sac-spawning euphausiid Nyctiphanes simplex in the northwestern seas of Mexico: Vertical and horizontal distribution patterns and seasonal variability of brood size. Deep-Sea Research Part II: Topical Studies in Oceanography 57 (7-8): 606-615. DOI: 10.1016/j.dsr2.2009.10.010

Heemstra P.C., Randall J.E. 1993. FAO species catalogue. Vol. 16: Groupers of the world (family Serranidae, subfamily Epinephelinae): an annotated and illustrated catalogue of grouper, rockcod, hind, coral grouper and lyretail species known to date. FAO Fisheries Synopses Series 125. FAO, Rome.

Helfman G.S., Collette B.B., Facey D.E., Bowen B.W. 2009. The diversity of fishes: Biology, evolution, and ecology. Wiley-Blackwell, Chichester, UK.

Hobson E.S. 1968. Predatory behavior of some shore fishes in the Gulf of California. United States Department of the Interior, Fish and Wildlife Service, Bureau of Sport Fisheries and Wildlife, Research Report No. 73.

Hoyle J.A., Keast A. 1987. The effect of prey morphology and size on handling time in a piscivore, the largemouth bass (Micropterus salmoides). Canadian Journal of Zoology 65 (8): 1972-1977. DOI: 10.1139/z87-300
Hurlbert S.H. 1978. The measurement of niche overlap and some relatives. Ecology 59 (1): 67-77. DOI: $10.2307 / 1936632$

Hyslop E.J. 1980. Stomach contents analysis-A review of methods and their application. Journal of Fish Biology 17 (4): 411-429. DOI: 10.1111/j.10958649.1980.tb02775.X

Iverson L.K., Pinkas L. 1971. A pictorial guide to beaks of certain eastern Pacific cephalopods. Fish Bulletin No. 152: 83-105.

Jiménez-Valverde A., Hortal J. 2003. Las curvas de acumulación de especies y la necesidad de evaluar la calidad de los inventarios biológicos. Revista Ibérica de Aracnología 8: 151-161.

Krebs C.J. 1989. Ecological methodology. Harper and Row Publishers, New York NY, USA.

Lavín M.F., Marinone S.G. 2003. An overview of the physical oceanography of the central Gulf of California. Pp. 173-204. DOI: 10.1007/978-94-0100074-1 11 In: Velasco Fuentes O.U., Sheinbaum J., Ochoa J.L. (eds.) Nonlinear processes in geophysical fluid dynamics. Springer-Science+Business Media, BV, Dordrecht, the Netherlands. DOI: 10.1007/97894-010-0074-1

Linde M., Grau A.M., Riera F., Massutí-Pascual E. 2004. Analysis of trophic ontogeny in Epinephelus marginatus (Serranidae). Cybium 28 (1): 27-35.

Lowry M.S. 2011. Photographic catalog of California marine fish otoliths: Prey of California sea lions (Zalophus californianus). NOAA Technical Memorandum NMFS SWFSC 483.

Martínez-Zavala M.A., Nevárez-Martínez M.O., Anguiano-Carrazco M.L., Santos-Molina J.P., Godínez-Cota A.R. 2010. Captura de peces pelágicos menores en el Golfo de California, temporada de pesca 2007-2008. Ciencia Pesquera 18 (2): 5-18.

Miller D.J., Lea R.N. 1972. Guide to the coastal marine fishes of California. Fish Bulletin No. 157: 1-235.

Moreno-Sánchez X.G., Abitia-Cardenas L.A., TrujilloRetana G., Navia A.F., Ramírez-Pérez J.S., Shirasago-German B. 2016. Variation of feeding habits of Lutjanus peru (Actinopterygii: Perciformes: Lutjanidae) caught in two regions of the Gulf of California, Mexico. Acta Ichthyologica et Piscatoria 46 (2): 97-108. DOI: 10.3750/AIP2016.46.2.05

Mullaney M.D.jr. 1994. Ontogenetic shifts in the diet of gag, Mycteroperca microlepis, (Goode and Bean) (Pisces: Serranidae). Pp. 432-445. In: Proceedings of the 43rd Gulf Caribbean Fish Institute.

Nikolsky G.V. 1963. The ecology of fishes. Academic Press, New York NY, USA.

Oksanen J., Blanchet F.G., Friendly M., Kindt R., Legendre P., McGlinn D., Minchin P.R., O'Hara R.B., Simpson G.L., Solymos P., Stevens M.H.H., Szoecs E., Warner H. 2015. vegan: Community Ecology Package. R Package version 2.2-1. http:// CRAN.R-project.org/package =vegan

Parrish J.D. 1987. The trophic biology of snapper and grouper. Pp. 405-463. In: Polovina, J.J., Ralston S. 
(eds.) Tropical snappers and groupers: Biology and fisheries management, Westview Press, Boulder CO, USA.

Parrish, J.K. 1992. Levels of diurnal predation on a school of flat-iron herring, Harengula thrissina. Environmental Biology of Fishes 34 (3): 257-263. DOI: $10.1007 / \mathrm{BF} 00004771$

Pereira P.H.C., Barros B., Zemoi R., Ferreira B.P. 2015. Ontogenetic diet changes and food partitioning of Haemulon spp. coral reef fishes, with a review of the genus diet. Reviews in Fish Biology and Fisheries 25 (1): 245-260. DOI: 10.1007/s11160-014-9378-2

Pérez-Olivas A., Irigoyen-Arredondo M.S., MorenoSánchez X.G., Villalejo-Fuerte M.T., AbitiaCárdenas L.A., Escobar-Sánchez O. 2018. Reproductive biology of the leopard grouper Mycteroperca rosacea (Streets, 1877) in the coastal area of Santa Rosalía, BCS, Mexico. Latin American Journal of Aquatic Research 46 (4): 699-708. DOI: 10.3856/vol46-issue4-fulltext-7

Pinkas L.S., Oliphant M., Iverson I.L.K. 1971. Food habits of albacore, bluefin tuna, and bonito in California waters. Fish Bulletin No. 152: 1-105.

Randall J.E. 1998. Groupers, seabasses, and their allies. Pp. 195-199. In: Paxton J.R., Eschmeyer W.N. (eds.) Encyclopedia of Fishes. 2nd edn. Academy Press, San Diego CA, USA.

Reñones O., Polunin N.V.C., Goni R. 2002. Size related dietary shifts of Epinephelus marginatus in a western Mediterranean littoral ecosystem: An isotope and stomach content analysis. Journal of Fish Biology 61 (1): 122-137. DOI: 10.1111/j.1095-8649.2002. tb01741.x

Roden G.I. 1964. Oceanographic aspects of Gulf of California. Pp. 30-58. In: van Andel T.H., Shor G.G.jr. (eds.) A Symposium: Marine Geology of the Gulf of California. Memoir No. 3. American Association of Petroleum Geologists, Tulsa OK, USA.

Rosa D.M., Vilar C.C., Musiello-Fernandes J. 2015. Relative effect of seasonality and body size on the diet of juvenile Lutjanus synagris (Perciformes: Lutjanidae) at a sandy beach in southeastern Brazil. Boletim do Instituto de Pesca 41 (1): 19-29.

Sadovy Y. 1994. Grouper stocks of the western Central Atlantic: The needs for management and management needs. Pp. 43-64. In: Proceedings of the 43 Gulf and Caribbean Fisheries Institute.

Santamaría del Ángel E., Álvarez-Borrego S., MüllerKarger F.E. 1994. Regiones biogeográficas del Golfo de California, basadas en las imágenes del Coastal Zone Color Scanner. Pp. 63-81. In: González Farías, F., J. Rosa-Vélez (eds.). Temas de oceanografía biológica en México. Universidad Autónoma de Baja California (UABC), Ensenada BC, México.

St John J. 1999. Ontogenetic changes in the diet of the coral reef grouper Plectropomus leopardus (Serranidae): Patterns in taxa, size and habitat of prey. Marine Ecology Progress Series 180: 233-246. DOI: 10.3354/meps 180233
St. John J. 2001. Temporal variation in the diet of a coral reef piscivore (Pisces: Serranidae) was not seasonal. Coral Reefs 20 (2): 163-170. DOI: 10.1007/ s003380100152

St John J., Russ G.R., Brown I.W., Squire L.C. 2001. The diet of the large coral reef serranid Plectropomus leopardus in two fishing zones on the Great Barrier Reef, Australia. Fishery Bulletin 99 (1): 180-192.

Stephens D.W., Krebs J.R. 1986. Foraging theory. Princeton University Press, Princeton NJ, USA.

Thayer G.W., Schaff W.E., Angelovic J.W., LaCroix M.W. 1973. Caloric measurements of some estuarine organisms. Fishery Bulletin 71 (1): 289-296.

Thomson D.A., Findley, L.T., Kerstitch A.N. 2000. Reef fishes of the Sea of Cortez. The rocky-shore fishes of the Gulf of California. Revised edition. The University of the Texas Press, Austin TX, USA.

Wainwright P.C. 1987. Biomechanical limits to ecological performance: Mollusc-crushing in the Caribbean hogfish, Lachnolaimus maximus (Labridae). Journal of Zoology 213 (2): 283-297. DOI: 10.1111/j.14697998.1987.tb03704.x

Wainwright P.C., Barton A.R. 1995. Predicting patterns of prey use from morphology of fishes. Environmental Biology of Fishes 44 (1-3): 97-113. DOI: 10.1007/ BF00005909

Werner E.E. 1977. Species packing and niche complementary in three sunfishes. American Naturalist 111 (979): 553-578.

Whitehead P.J.P. 1985. FAO species catalogue. Vol. 7. Clupeoid fishes of the world. An annotated and illustrated catalogue of the herrings, sardines, pilchards, sprats, shads, anchovies and wolf-herrings. Part 1. Chirocentridae, Clupeidae, and Pristigasteridae. FAO Fisheries Synopsis No. 125.

Winemiller K.O. 1989. Patterns of variation in life history among South American fishes in seasonal environments. Oecology 81 (2): 225-241. DOI: 10.1007/BF00379810

Wolff G.A. 1984. Identification and estimation of size from the beaks of 18 species of cephalopods from the Pacific Ocean. NOAA Technical Report NMFS 17.

Zapata L.A., Rodríguez G., Beltrán B., Gómez C., Angulo W., Gómez A., Ramírez M., Morales J., Hung M., Herrera J., Riascos C. 1999. Prospección de los principales bancos de pesca en el Pacífico Colombiano, durante noviembre de 1998. Boletín Científico INPA 6 (1): 111-175

Zhuang X., Qu M., Zhang X., Ding S. 2013. A Comprehensive description and evolutionary analysis of 22 grouper (Perciformes, Epinephelidae) mitochondrial genomes with emphasis on two novel genome organizations. PLoS ONE 8 (8): e73561. DOI: 10.1371/journal.pone.0073561

Received: 10 October 2017

Accepted: 10 November 2018

Published electronically: 15 March 2019 